\title{
On Planigraphy of the Early Nomadic Steppe Necropolises with the Series of Women-Warriors
}

\author{
Sergey Yatsenko* \\ Department of the History and Theory of Culture, Russian State University for the Humanities, Russia
}

Submission: March 25, 2019; Published: April 01, 2019

*Corresponding author: Sergey Yatsenko, Department of the History and Theory of Culture, Russian State University for the Humanities, Moscow, Russia

\begin{abstract}
Planigraphy studies of both small necropolises with 1-2 female graves and female grave series in large cemeteries is a very promising issue. These findings reflect features of military and political situations, clan and family hierarchy, details of different aspects of a particular woman's status (family, ritual, personal), circumstances surrounding the death. Probably, special personal military merits in the past and a family status of a dead woman were the main reasons to place weapons in her grave. The set of weapons put into a female grave differs from the one in a male grave. There were some "additional"arms items that, excluding arrowheads, depended partly on the age group (Mamai-Gora) or the grave type connected with a particular clan (Novyi). In western regions of the Steppe, women-warriors' graves have practically not been identified. In the west, in the key-zones of Scythia (the Lower Dnepr and North-West Azov Coast) and in Sarmatia (the Lower Don), with their best pastures and the abundance of dangerous enemies, these women were more in number. Probably, all women underwent military training in zones of frequent conflicts. However, many were buried at the battlefield but putting symbolic items of weapon into the grave was not acceptable for every woman. Weapons in female graves are more often found in burials of long time ago married women sometimes buried together with children. 1-2 of such graves per a necropolis often marked personages of high status in the community. One item of rare weapons in the grave (1-3 spears, armor for Scythians, a battle axe, a long sword or three different blades for Sarmatians) sometimes was enough to mark the status of a noble woman.

Keywords: Nomadic archaeology; women-warriors; necropolises Planigraphy; Scythians and Sarmatians; Social status in various communities
\end{abstract}

\section{Introduction}

Ancient authors tell us a significant number of important things about nomadic women-warriors. For Yazatamates and probably for neighboring Siraces of the $1^{\text {st }}$ c. CE we have detailed realistic descriptions of collective hunting (sometimes, military) trainings for all women beginning from adolescence and also of their weapon specificities. (Pomp. Mela. De citu orbis. 1.21. 5 and 114; 3. 4. 34-35). There are still some legends about historical figures - mighty women-warriors that would match for men in strength and military feats (Diod. Syc. II, 44-46; Pomp. Trogus. Hist. Philip. II, 1, 4; Stesias. Pers. Hist.; Polyaen. Strat. 8.). On the Danube in 275 CE, Romans were not able to tell Sarmatian warrior women from men, either judging by their behavior or by the way they looked (SHA. Avrelian. 22). Special squads of warrior women are episodically mentioned in archaic "Nart" epic poems of Ossetians, successors of Sarmatians [1], and such practice may also have been followed by ancient Sauromates [Herod. 4. 116]. Engaging women's participation in military activities was convenient for nomads as from their childhood women were good horse riders, took part in group hunting and learned to protect themselves.

As to social interpretation of female graves with weapons, in the minds of colleagues we see the real chaos. Today in literature there are many explanations why a single item or a series of weapons were placed in women's graves of ancient nomads. The main interpretations of this fact are as follows: (1) evidence of women's real participation in military actions; (2) reflection of "female" status as close to "male"; (3) ritual attributes, amulets; (4) respect for the dead women by male relatives; (5) means of protection on the way to the hereafter for women deprived of protection; (6) gifts to the deceased husband; (7) result of the destruction of a male burial or symbolic burial where a woman was only a human sacrifice [2]. Many of these interpretations look even at the first approximation very exotic and speculative. On the whole, there is no single point of view on social interpretation of such burials. It is far from clear, to what extent the existence of such burials reflects a true picture of an entire nomadic people being a unified army; what exactly the predominant age of the dead indicates; whether the warrior's accoutrement was a complete and true arms set at a war; whether participating in wars enhanced women's status; what differs noble ladies' arms from those of commoners'. Whereas previously researchers were convinced that weapons in female graves were traces of former military activity of the dead, today the scientific "fashion", as it often happens has swung to the opposite direction: some researchers believe that women have 
never fought, and the weapons in their graves are only a symbol. But what exactly did they symbolize? These authors cannot clearly explain and ground such "symbolism" (with references to historical and ethnological analogies, etc.).

In the small number of graves with weapons they see confirmation of this interpretation. In my opinion, such a conclusion is possible because of fragmented notion of important facts (some quite reliable written data on Sakas and Sarmatians; traces of specific combat injuries of some women buried with weapons; recent materials on women-warriors of pastoral tribes in Eastern Africa, Rajputs of India etc.). Actually, even issue experts' study single and isolated burials and often the big necropolises without any anthropological identification [2-4]. From their point of view, a single arrowhead in a female grave mark it as a burial of "an armed woman" $[2,4]$ (whereas, for Eurasian nomads, an arrowhead was a usual amulet for mothers up to the $20^{\text {th }}$ c.). On the whole, some skepticism of leading specialists about socio-cultural content of armed women's burials (the very small number of such burials is considered confusing and so forth) is not entirely founded [5]. Probably, it is not easy to look for the trustworthy demographic or social crosssection of the epoch on the available materials from barrow necropolises. However, these data, if appropriately processed, could result in additional possibilities for socio-cultural status interpretation of these women who, judging by their age, were practically always married, typically for traditional societies. Archaeological research of nomadic women-warriors of the Antiquity is complicated by grave robberies at different periods and also, the absence of trustworthy age and gender identification (the latter have mostly been done for single elite burials whereas the rest of the bones have not been kept; anthropologists are often not interested in probable traces of "rider's strain" and battlefield injuries).

Most likely, the greatest number of female corpses remained at the battlefield and did not get to clan cemeteries (the low percentage of women with battlefield injuries buried with weapons illustrates this point). Furthermore, if all women in a tribe had to take part in a war, due to their merit, hereditary status and circumstances surrounding death, not each of them was buried with any weapons at all (especially if a woman had not taken part in hostilities since long ago). Archaeological research of nomadic women-warriors of the Antiquity is complicated by grave robberies at different periods and also, the absence of trustworthy age and gender identification (the latter have mostly been done for single elite burials whereas the rest of the bones have not been kept; anthropologists are often not interested in probable traces of "rider's strain" and battlefield injuries). Most likely, the greatest number of female corpses remained at the battlefield and did not get to clan cemeteries (the low percentage of women with battlefield injuries buried with weapons illustrates this point). Furthermore, if all women in a tribe had to take part in a war, due to their merit, hereditary status and circumstances surrounding death, not each of them was buried with any weapons at all (especially if a woman had not taken part in hostilities since long ago).

In my view, the analysis of necropolises Planigraphy (both small and large ones) opens up new perspectives for studying cultural and social phenomenon of female warriors. Vast necropolises, unusual for Steppe nomads, also included large grave series of such women. The necropolises were of barrow type (Scythian Mamai-Gora with 367 graves [6] and Novyi of the Middle Sarmatian Culture with184 graves and remains of 228 people $[7,8]$ and ground ones (Skel'ki [9]). They were, probably, located in sacred places (by sacred springs or trees, by the grave of a most holy ancestor). Researchers usually avoid a detailed systematic analysis of necropolises and do not compare them. Yet "Amazon" materials on two of them were studied, preliminary and incompletely, though (see Mamai-Gora [3]; Novyi [10]). My recent observations on them [11-13] also need development.

\section{Scythia of the late $5^{\text {th }}-4^{\text {th }} \mathrm{cc}$. BCE}

The barrow necropolises of Scythians in which we find more than two women-warriors are not numerous. They are known in two main zones: in the Lower Dnepr River (the political and economic center of Scythia) and along the eastern border with Scythian enemies - Sauromates and Early Sarmatians (Figure 1). The largest necropolis of Scythia - Mamai-Gora - is by far the most interesting one. It belonged to poor nomadic clans of the late $5^{\text {th }}$ and $4^{\text {th }}$ cc. BCE. They buried their dead very densely in graves of three types. There were not less than fifteen women-warriors buried here in all types of graves, mostly in alcove graves, domineering in number (8), and only one - in a pit (Figure 2). We probably observe a well-thought-out composition of armed women burials. The alcove graves form two accumulations in the western and eastern parts of the cemetery ( 3 to 5 graves in each part); in the center, there are five catacombs, located along the northern and southern borders of the cemetery; the only pit is situated at the eastern border (the other graves of that type are chaotically scattered, an average of 1 to 2, throughout the whole area). Apparently, women of early marriageable age (12-20 years old) should have prevailed among the armed ones. In fact, there are none at all. Women of 25-30 years old are predominant in alcove graves, and in catacombs, we find the age group of 30-35 (the life expectancy of that time being low, those women were rather elderly) that is those that stopped fighting long ago. Battlefield injuries are observed for such women. However, the material has not been published by anthropologist L.V. Litvinova yet. More often, a grave with weapons is one of many among 3-10 graves of supposed relatives in the barrow. Sometimes, in all the three types of graves there are joint burials of a woman with an adult man (a husband if her age or a farther if twenty years older) who both died concurrently of disease or hunger. However, burials with children (to differ from other necropolises) have not been discovered here.

Usually, of all weapons, there are only arrows placed into female graves (a sword is an exclusively man's attribute in 
Mamai-Gora). Unless these graves have been robbed (actually, all the five alcove graves in the eastern part of the cemetery have not been robbed), here women over 25 years old have a quiver with 20-50 arrows, whereas in catacombs they have either less than 20 or more (up to 45 ones). The number of arrows placed in the grave was defined by the age: all quivers with more than 20 arrows in them are only known for the age group from 25 to 35 years old; for women under 25 and over 35, the number of arrows is smaller.
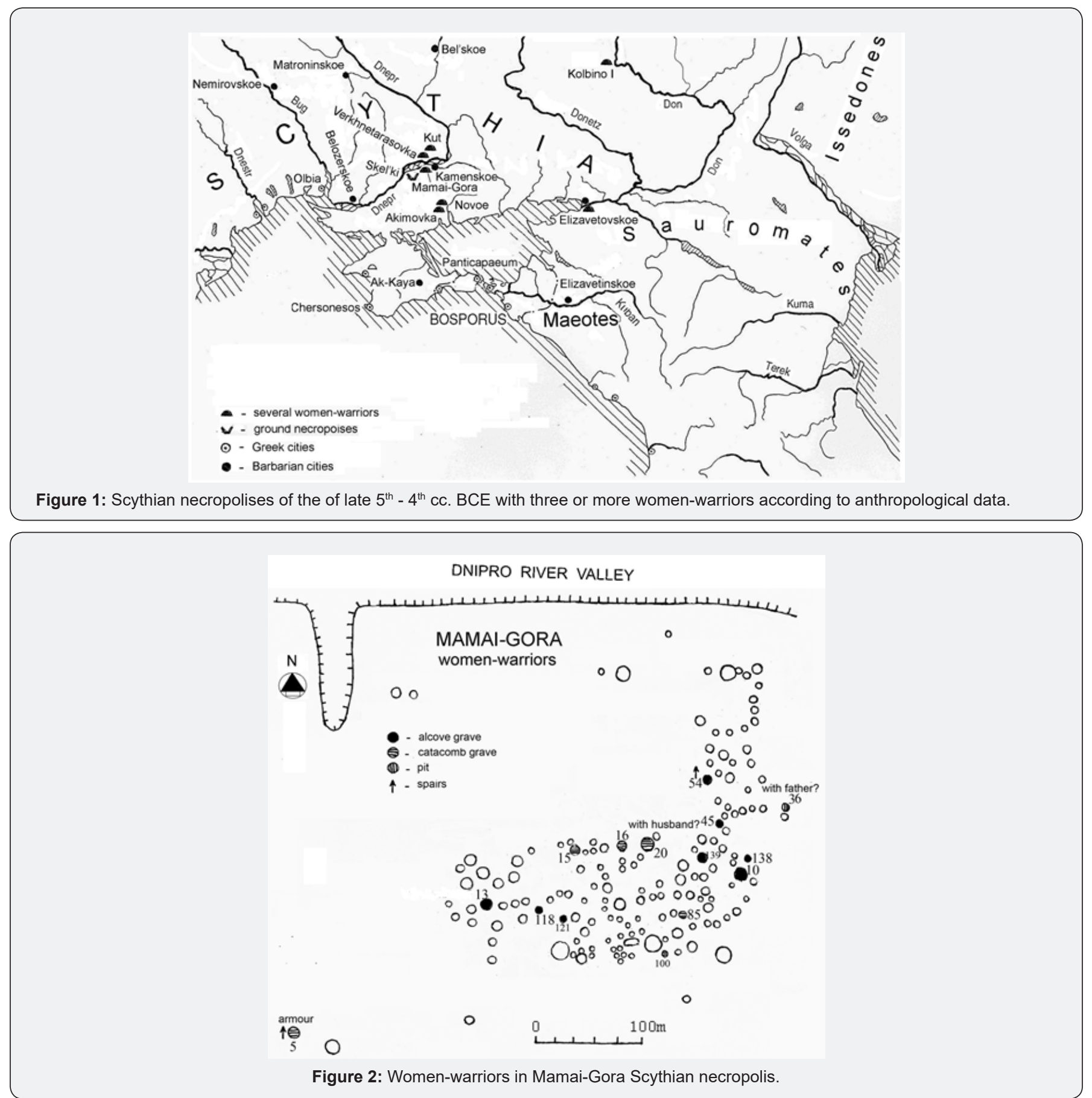

Besides, apart from arrows, two ladies from the older age group (30-35 years old) in barrows at the necropolis edges have additional weapons (1-2 spears) (barrows 5, 54); in the first case (the most influential one among local women) the arms set is completed with a scale armor and a pair of bolas. In this poor necropolis, artifacts made of gold and silver are discovered only in catacombs, almost always in female graves. The only burial of a female warrior of such type which has not been robbed (barrow 16, grave 1) contains a silver torque, a gold seal-ring, some necklaces, a quiver with 45 arrows. Just $1 / 5$ of womenwarrior's burials were looted; this percentage is lower than the average for female graves. Many accessories of women-warriors' costume (to differ from women who were not liable for military service) do not depend on the grave type and are defined by their 
age. Thus, in the age group from 25 to 35 years old, 1-3 earrings have been found (barrows 45, 85, 139), the same age group used buckles and buttons (barrows 100,118, 139). Beginning from
30-35 women-warriors used to wear 1-2 seal-rings (barrows 13, 100).

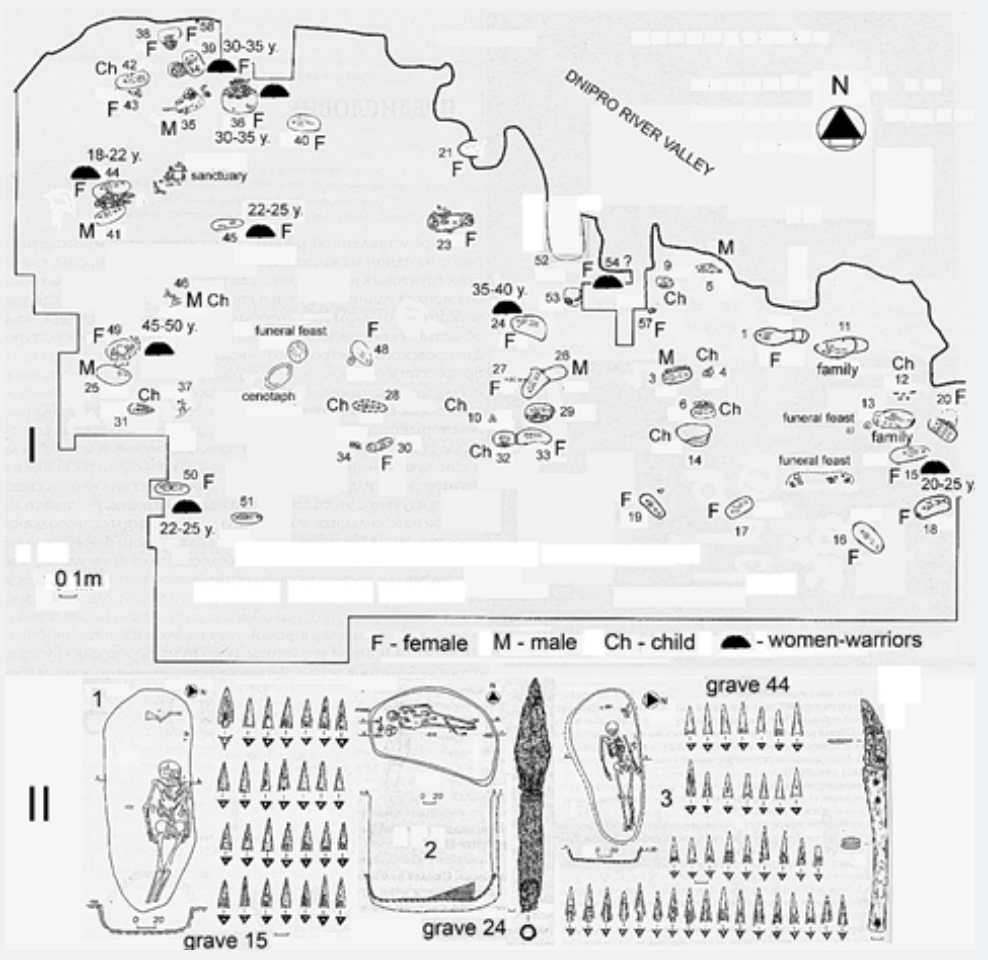

Figure 3: Women-warriors in Skel'ki ground cemetery: I - plan; II - the most important women-warriors graves.

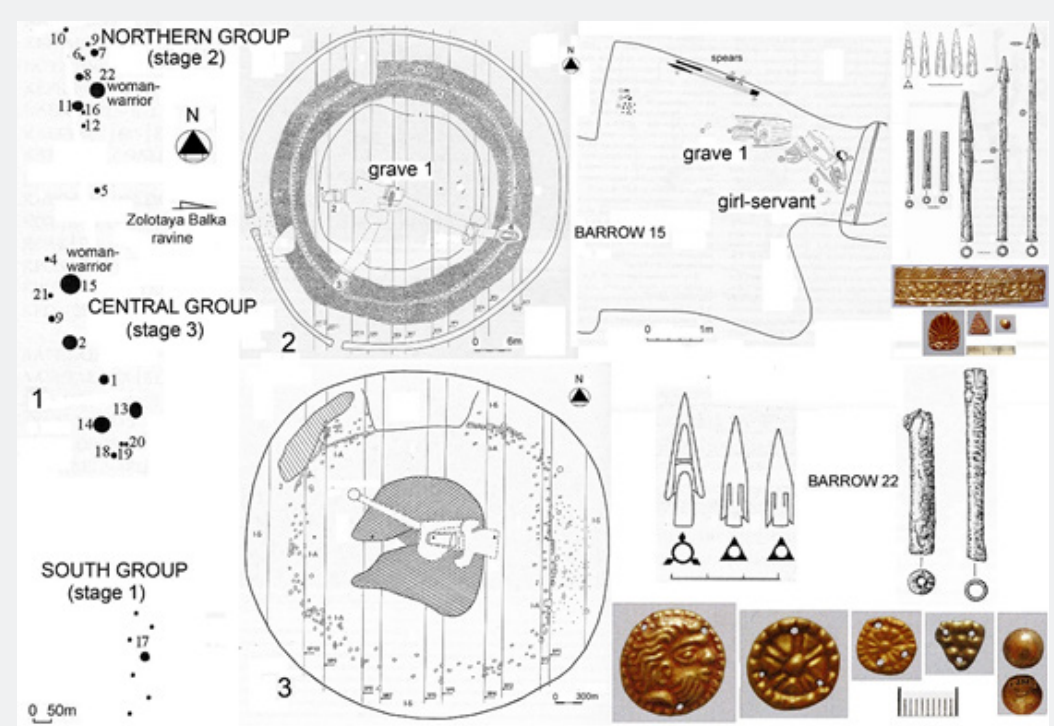

Figure 4: Ryadovye Mogily Scythian necropolis: 1 - plan; 2-3 - barrows 15 and 22 [15].

A poor Scythian ground necropolis Skel'ki with 9 womenwarriors [14] (Figure 3) presents a certain interest not only due to its big size but also due to the domineering number of women (23) and children (15) over men (10) buried here. Graves of female warriors (excluding № 15) are located not in the main zone of family and children burials in the east, but in the west and north-west. Another interesting specificity observed here is that ritual complexes close to the graves, in two cases of three refer to women-warriors namely (burials 15 and 33, the eastern and western edges of the cemetery). Weapons are usually found here in graves of women from the age group of 20-25 years old. The only grave (24) with weapons which differs from traditional arrows (a spear) belongs to an elderly woman, the same as in Mamai-Gora; and there are only two instances when a set of arrows (more than 25 ones) in a quiver were put into a burial but not just a bunch of arrows (Figure 3, II). These 
more sophisticated weapons are known only for pits and not for catacombs (which, probably, reflects traditions and prestige of different clans). Women with weapons, to differ from MamaiGora, are distributed equally between the two graves types (catacombs and pits), whereas in family burials (a husband
+ a wife + a child) there are no weapons belonging to women. Women-warriors are sometimes buried with a child 1.5 years old (grave 25) or an adolescent (grave 39) (children buried in Skrl'ki are usually of another age: from 5 to 8 years old).

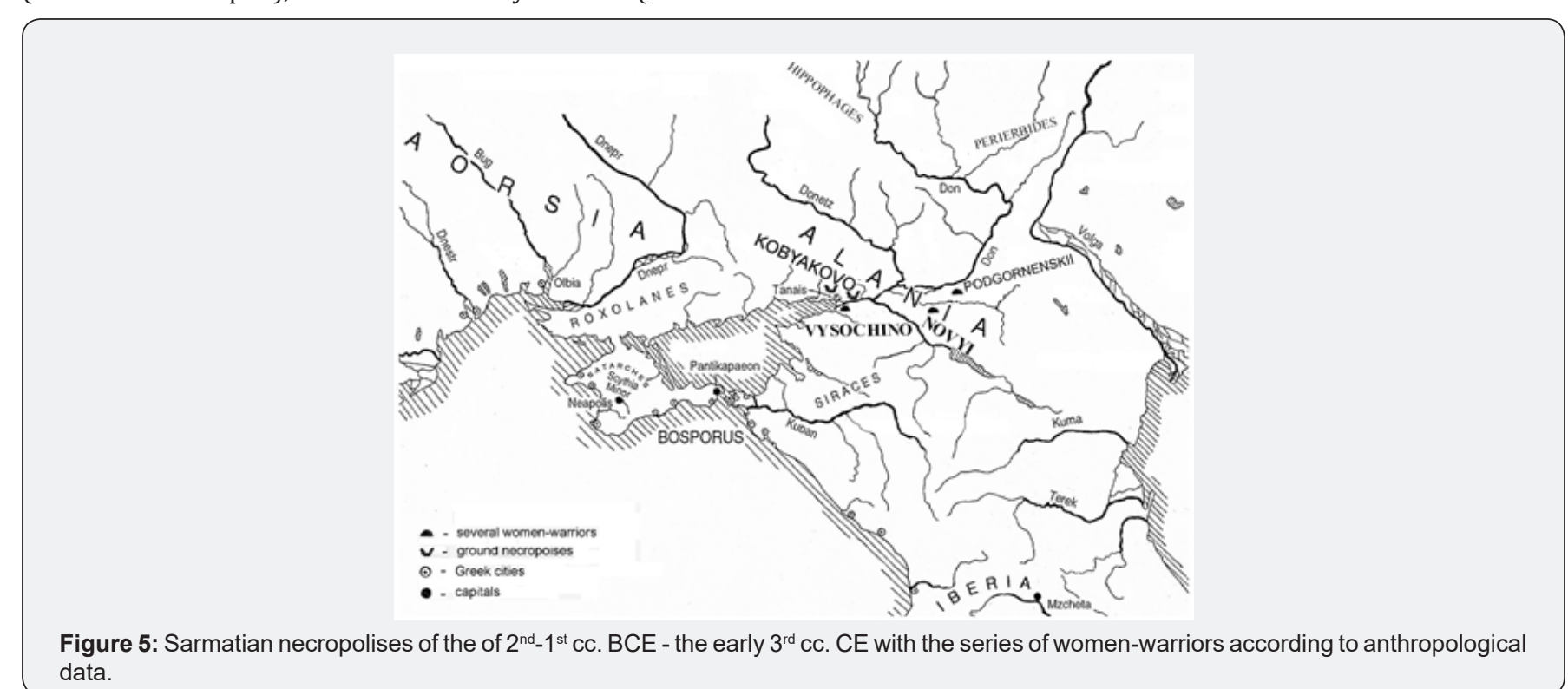

data.

The analysis of the necropolis containing among others only two graves of women-warriors is of no less importance. It is located, as the both above mentioned ones, on the Lower Dnepr. Ryadovye Mogily by the village of Zolotaya Balka forms three groups of barrows along the north-south line [15] (Figure 4). Each group of barrows with one high barrow of a leader in the center belonged, probably to a family. The southern group of small mounds is the earliest one (the turn of the $5^{\text {th }}-4^{\text {th }}$ Cc. BCE); a man is buried in the central barrow (1.3 m high). The central and northern groups are quite different. Here the main burials in the highest barrow (5.1 - $6.0 \mathrm{~m}$ high, Ns. 15, 22) belong to women-warriors (No 15 - the central and the highest one - was created for a woman of 22-25 years old in the second quarter of the $4^{\text {th }}$ c. BCE; and the northern No 22 was made in the middle of the century for a woman over 30). The both women might have had three spears each, a quiver with arrows and a costume richly decorated with gold applications - everything damaged by grave robbers (Figures 5-7); there is a female servant, murdered and buried close to each mistress. In this necropolis it was women-warrior's barrows that formed the central element of the cemetery, and these women were most luxuriously seen off to another world.

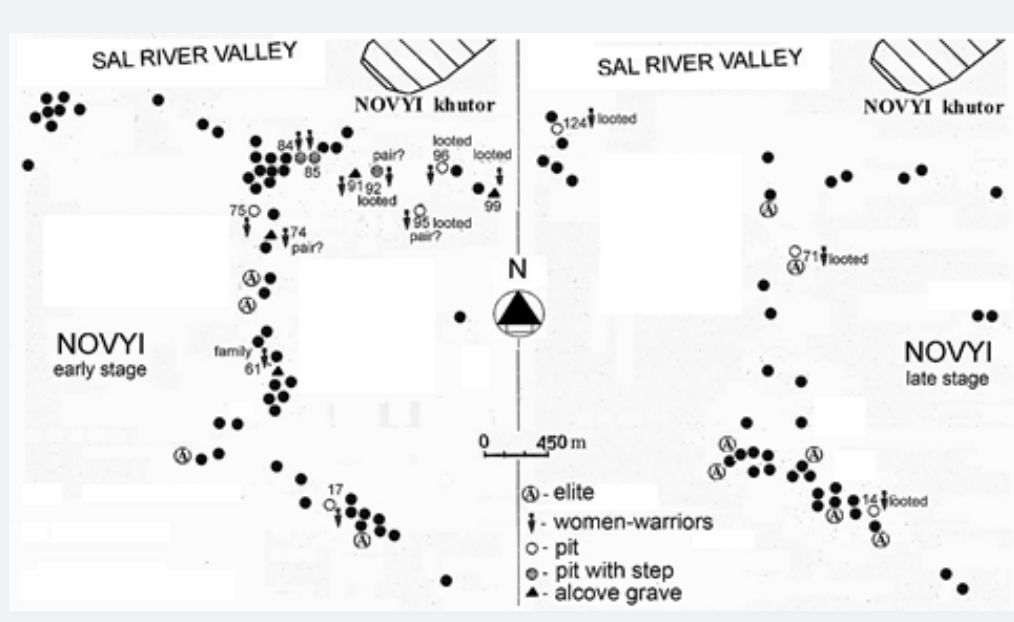

Figure 6: Women-warriors in Novyi Sarmatian necropolis.

On the whole, if a quiver with arrows was a usual set, then 1-4 spears, sometimes an armor, were less frequent and more prestigious for Scythian women-warriors (Mamai-Gora, barrow 5; Kolbino I, barrow 5). A sward can be added to this list at the western border of Scythia -in the Middle and Lower Don Basin (Elizavetovskoe, barrows 30, 51, 130; Severnyi I, barrow 3; Sladkovka, barrow 4) [4]. 


\section{Global Journal of Archaeology \& Anthropology}

Sarmatia of the late 1 st c. BCE - early $3^{\text {rd }}$ c. CE

Necropolises of late $1^{\text {st }}$ c. BCE - mid. $3^{\text {rd }}$ c. CE, belonging to nomads who created three "Sarmatian Cultures", were concentrated in the most important economical center and the region of best grazing land - the Lower Don (Figure 5). The ethno-political map shows information for the late $1^{\text {st }} \mathrm{c}$. CE. Necropolis Novyi in the Sal Steppe dated mostly back to the $1^{\text {st }}$ c. CE and having two stages in its history was the earliest and most important one (Figure 6). Male burials are most numerous here. However, the percentage of children's graves is also high (25\%). There are 14 burials of women-warriors $20.5 \%$ of all women here). The greatest number of graves (including femalewarriors: 11 from 14) belong to the earlier stage which for many reasons was a stressful period of time for the community and was accompanied by conflicts with neighbors [12]. The same as in Mamai-Gora, female-warriors are presented here in all the three types of graves: mostly in pits, in pits with a step along the upper edge and alcove graves. The proportion of ancient robberies in them varies from 25 to $65 \%$. For the earlier period (Figure 6, left) pits and alcove graves are met in different parts of the cemetery, whereas pits with a step are concentrated in the small area at the border with the river valley. At the later stage of the cemetery existence, only pits were used for women-warriors (one in each of the three pits accumulations).
Arrows only have been preserved in graves of most womenwarriors ( 8 out of the 14). Although about $75 \%$ of these graves have been robbed and there is no certainty that such weapons prevailed, in three out of the four of barrows having a single grave, it is arrows namely that have been discovered: there are up to 46 arrowheads preserved even in robbed graves. It is interesting that there are sets of three arrows (the simplest sacred number) found in four graves (both robbed and not robbed: barrows 17, 75, 91, 95); probably, robbers did not touch this sacred set. In six more burials (in graves of all types belonging to different age groups) weapons are of another type and quite diverse: such as, a sword and a dagger (barrow 85), a sword and a combat knife (barrow 61), a sword (barrow 84), a dagger and arrows (barrow 74), an axe and a combat knife (barrow 71), an axe (barrow 96). In both pits with a step around the upper edge there is a sword; in both pits there is a battle axe. Novyi differs from Mamai-Gora, among other things, in that it has female-warriors under 20 years old (barrows 17, 74), a woman-warrior buried in one grave with two brothers (barrow 85 , all the three have a sword and a dagger), swords, battle axes and combat knives included into weapon sets, and also burials of adults with 1-2 small children (barrows 17, 74, 84, 91) while there are no separate graves for children here at the early stage of the cemetery's existence.

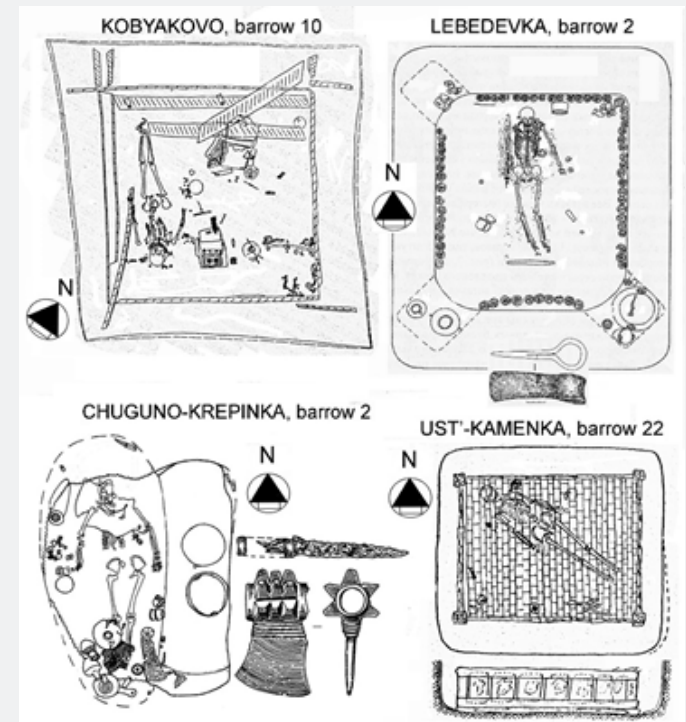

Figure 7: The noble female Sarmatian graves of the mid. $1^{\text {st }}$ early $3^{\text {rd }}$ Cc. CE with axes [17].

A woman under 20 in barrow 84 was buried together with a newborn baby, i.e. she had died during childbirth; her female counterparts in three other cases might have died of epidemics or famine, whereas the girl buried with brothers (?) in barrow 85 , grave 4 - had been scalped by enemies and died of that [16]. To differ from local male-warriors (whose traditional set of arms is a sword + arrows), female-warriors in Novyi do not have armours, spears, paired complexes of equipment (swords + a bridle), plate decorated belts or belts with gold/silver/gilded iron buckles. Women in Novyi do not have a single symbolic arrow - amulet which is such an often grave good for men. The most of women-warriors are definitely from poor families. However, the both women with battle-axes from ordinary pits in barrows 71, 96 (one woman per stage) belonged to the local elite as their costume includes gold dress applications, a silver ring. A comparatively high status of axe owners among "average Sarmatians" has been proved by many facts [17] (Figure 7). There are four women buried in single-grave barrows. Sometimes there are two graves in one barrow (a woman-warrior, her probable husband, seldom, her son- barrow 96); in one case there are two 
separate graves of children close to the female-warrior's grave a child, one of the women - a warrior, in a double alcove grave (barrow 99), in another case there are two women, each with (barrow 61).

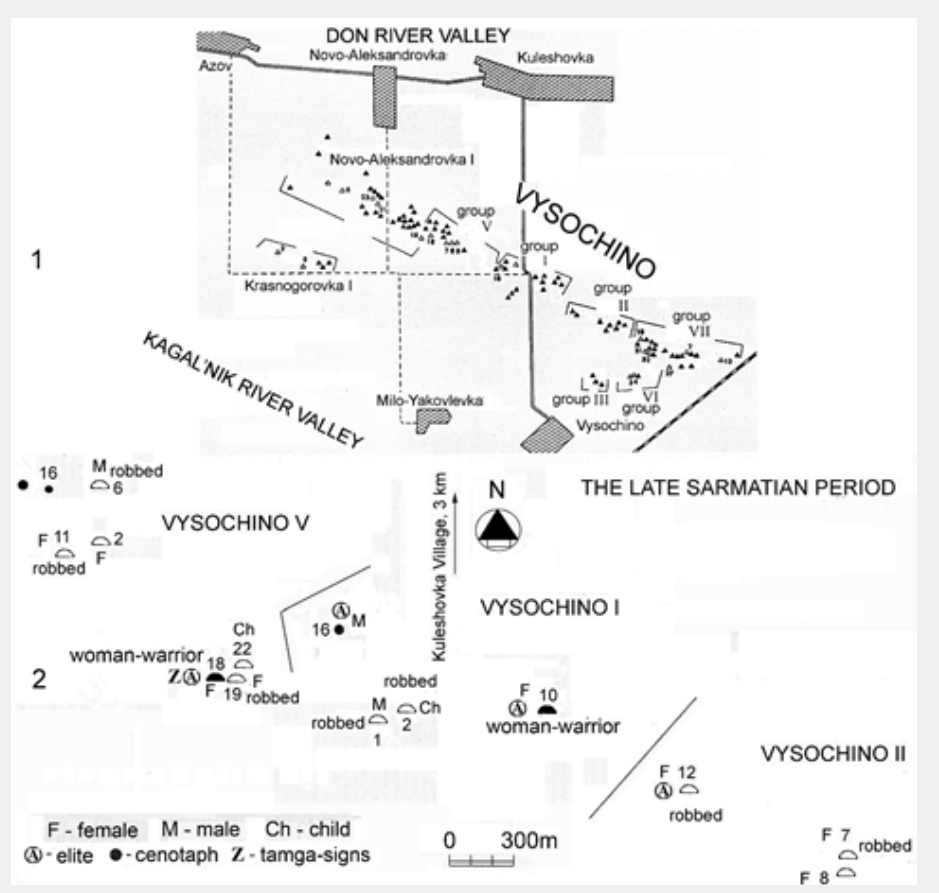

Figure 8: Map of Vysochino I-II-V Sarmatian necropolis, the late $2^{\text {nd }}$ - early $3^{\text {rd }} \mathrm{CC}$. CE.

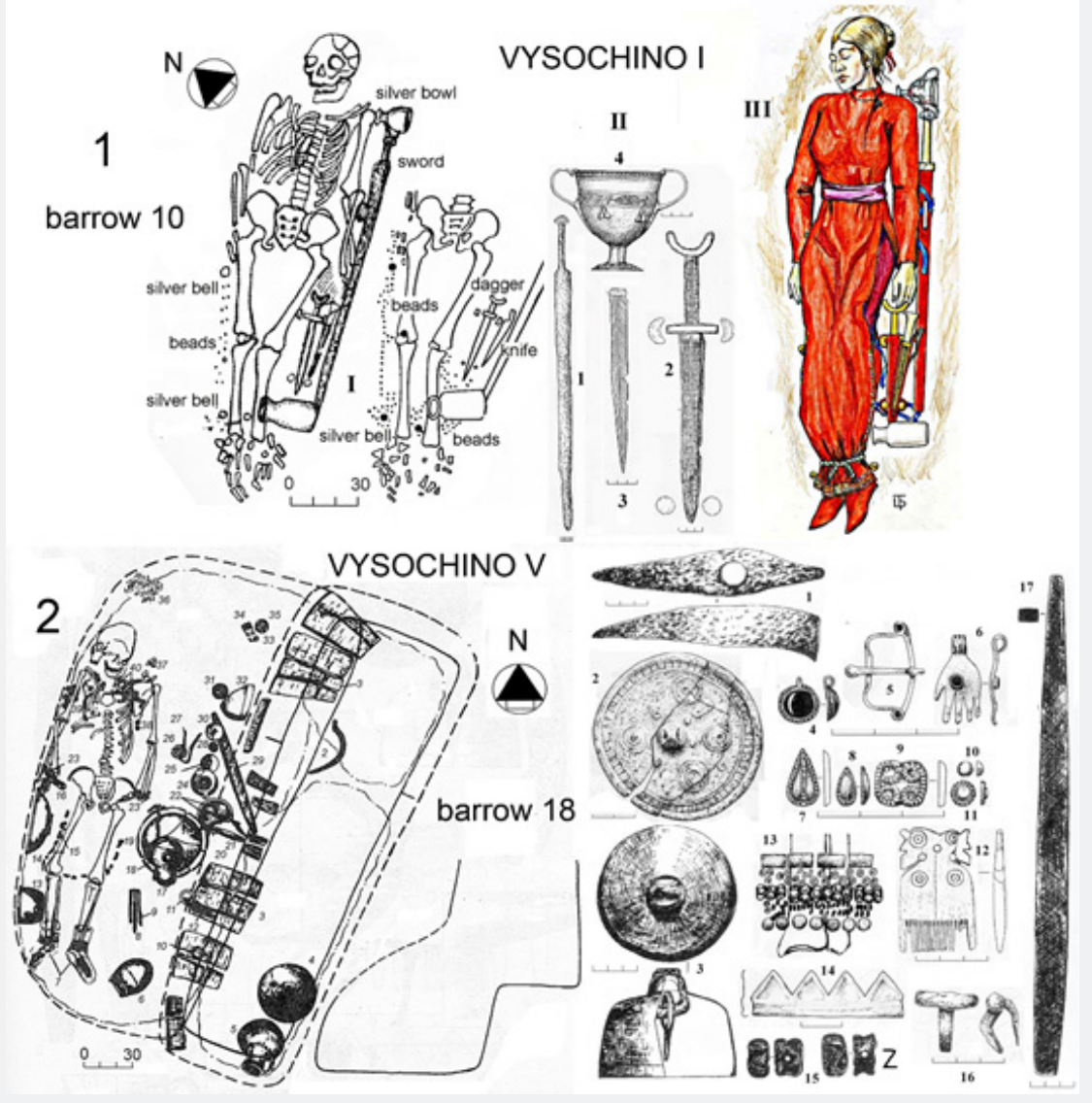

Figure 9: The noble women-warriors from Vysochino I and V (E.I. Bespalyi black-white drawings). 


\section{Global Journal of Archaeology \& Anthropology}

Data analysis on necropolises where only 1-2 femalewarriors 'graves are discovered is of no less interest. Let us consider the materials on the central part of the vast Sarmatian necropolis located at the Don estuary, on the left bank of the river, Vysochino I, II, V with 58 barrows [12,18], belonging to the Middle Sarmatian and beginning of Late Sarmatian Cultures. In each period of this mainly elite necropolis, women's barrows considerably dominated over male and children's (Middle Sarmatian - 14:7, Late Sarmatian - 8:3). In the Late Sarmatian time, four aristocratic barrows (three of them belonging to women) formed the center of the whole necropolis; each barrow presents a specific type of a burial (!). The only barrow which had been robbed is the easternmost female one (barrow 12, group II) (Figure 8) (B. Tsogoev color reconstruction). Two womenwarriors in parade costumes (barrow 10, group I; barrow 18, group V) are particularly interesting [19] (Figure 9). Two neighboring barrows of ordinary relatives or dependant peoples (an adult and a child) are connected with barrows of these two women. We can suppose that the woman from barrow 10 was of the highest rank in this necropolis: 30 amphorae of wine were broken on the barrow during the funeral repast, three different types of edged and bladed weapons are her grave goods (comp. female memorial statues of the $3^{\text {rd }}-1^{\text {st }}$ cc. BCE in Ustyurt Plateau, Western Kazakhstan (Figure 1). The woman from barrow 18 might have been slightly lower in rank, but she has; a status weapon - a battle axe, a silk dress decorated with a pattern made of gold thread, gold appliqués on the dress and headwear and a lot of expensive imported goods as her burial items. Actually, analogous to Scythian Ryadovye Mogily, women-warriors take the central and most honorable place in the composition of the necropolis.

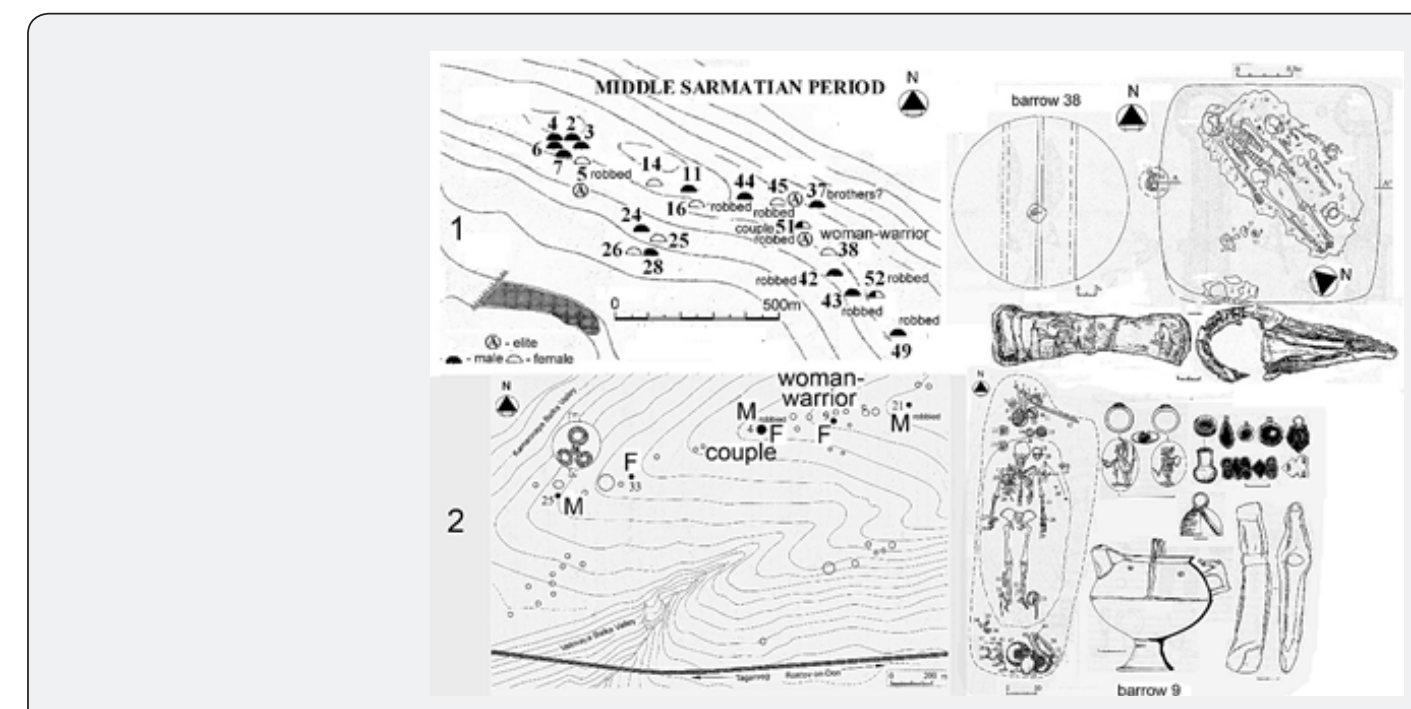

Figure 10: The female graves with axes: 1 - Peregruznoe I [Balabanova et all. 2014]; 2 - Valovyi I [21].

I will now offer examples of necropolises with only one woman-warrior whose burial is not the center of the composition. Nevertheless, she possessed attributes of high status and the axe, probably, among them. A very poor peripheral necropolis in the Lower Don Basin - Peregruznoe I [20], where there were created, besides others, 23 barrows belonging to the Middle Sarmatian Culture, is apparently opposite in many aspects to previously mentioned necropolises. Here, contemporaries looted females' graves more often (though, there were a smaller number of them if compared with males' graves) (Figure $1 \& 10$ ). During that period three high barrows (Ns 44, 45, 51) became the center of the cemetery's composition and soon were robbed. There are rough iron "staffs" $40 \mathrm{~cm}$ long in females' graves here. From the east, two smaller but not less significant burial mounds side the main barrows. In barrow 37 there are two young men of the same age (about 20-25 years old) with weapons of the same type (a sword and a bunch of arrows): they were, probably, sworn brothers (comp. Lucian. Tox. 37); barrow 38 contains the only burial of a woman-warrior under 4 with a baby. It is more modest than previously mentioned ones but has such attribute as a battle axe. So, it cannot be considered a common burial.
A chain of five barrows - Valovyi I [21] (Figure 2 \& 10) dates back to the beginning of the Late Sarmatian Culture. The layout of this elite necropolis containing six deceased only ( 3 men and 3 women) has clear gender symmetry. Ancient robbers acted quite selectively: they had not touched any females' graves (containing gold things), but two males' ones had been robbed. Among grave goods in females' graves there is an abundance of amulets and rare (evidently and mostly cultic) attributes. Barrow 4 is the highest. It is located in the center. The most powerful man was buried in it the first, and later - his wife (?). Her grave is very modest, it had a bunch of twigs tied together (it was used for fortune-telling by Iranian people). Two male-barrows form the necropolis's edges. The barrow of the main couple is between two female-barrows. The two women in these barrows were about 30 years old. Their grave goods are gold necklaces with garnets, bronze caldrons with zoomorphic handles and large Roman bronze-ware with depictions of naked male figures. Of these two, attributes of the woman from barrow 33 are far more modest: still they include a play set of 26 sheep kneecap and a tortoise shell bowl. The noble woman from barrow 9 is of the highest rank among other females in the necropolis. She is the 
only one with a weapon (a battle-axe), there are also 4 gold and silver finger rings with gems, a gold vial and a dress with many gold appliqués (often decorated with enamels), a set of four items of Roman bronze tableware, etc.

On the whole, a bundle of arrows is a usual grave good weapon for Sarmatian women (Pomp. Mela, 3. 34-35), 1-2 combat knives are less frequent. A lasso, another traditional weapon (Pomp. Mela. 1. 114), has not been preserved in graves. In the Lower Don of the $2^{\text {nd }}-1^{\text {st }} c c$. BCE the short swords were dominated [22]. Swords are mentioned neither by PseudoHippocrates (Aer. 24), nor by Pomponius Mela, as they were probably used by peripheral groups and outstanding womenwarriors. Battle axes of different types and, seldom, swords or Nomadic Women Integrated into Settled Cultures a bow without arrows were rarer and more prestigious in the $1^{\text {st }}$ - early $3^{\text {rd }}$ cc. CE (Novyi, Vysochino I, Kobyakovo). Battle axes of Sarmatian nobility were sometimes the specific attributes of power [23]. Today we know not less than 10 females' graves with battle axes (comp. on their ritual functions [24,25] (Figure 7). This conclusion is supported by the fact that noble women used stone battle axes-hammers of the Bronze Age as special scepters, and their fragments served as powerful amulets [26]. Some axes, under different circumstances, could be used whether as household tools, or weapons or symbols of power. Three items of bladed weapons or long sword may be considered a sign of a much higher status. To differ from the Scythian epoch, spears and bolas were not used by women.

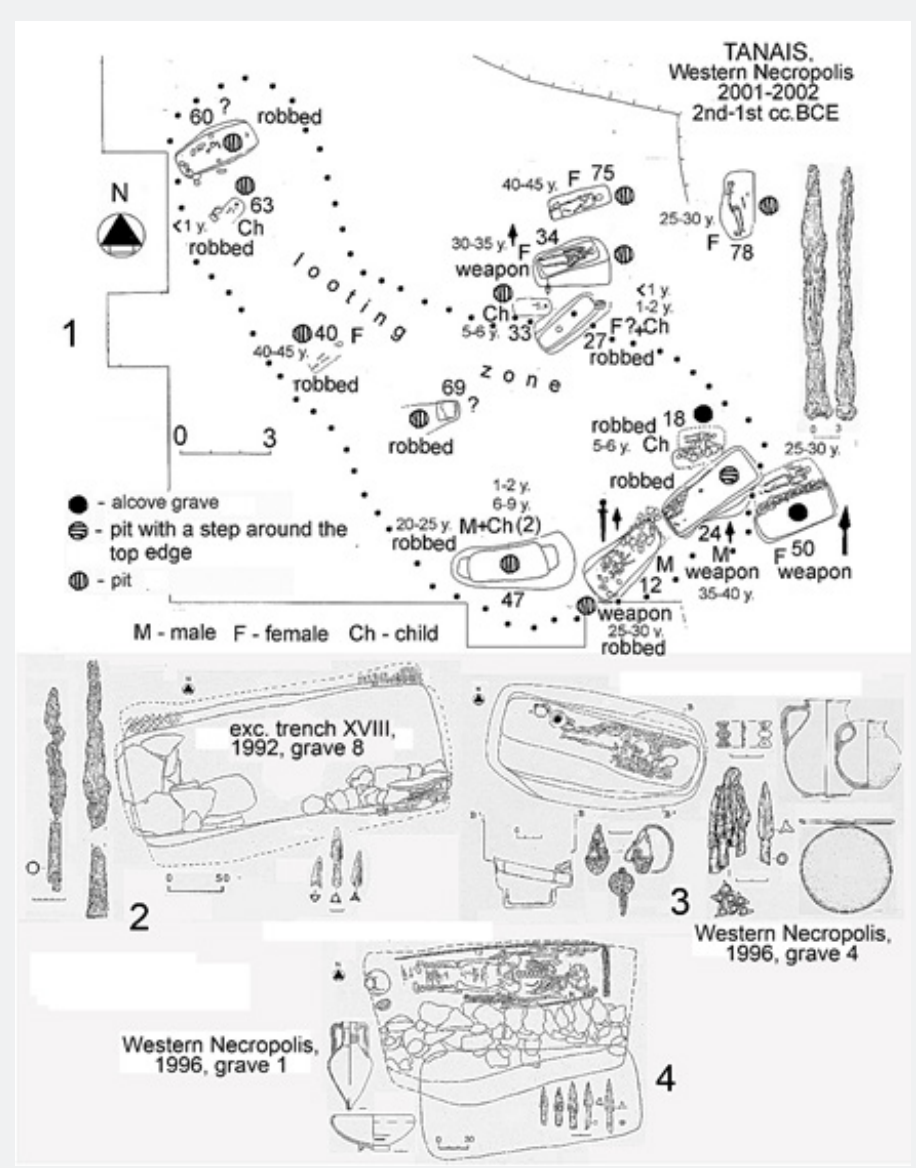

Figure 11: Tanais, Western Necropolis: 1 - excavation trench of 2001-2002 yy. (based on I.I. Tolochko plan); 2-4 - the most important graves [22].

In such important center of the Sarmatian World as the River Don Mouth, mixed marriages between Sarmatian women and men, belonging to neighboring sedentary peoples, present significant interest. By force of habit, in patriarchal society, such women had to become integrated into foreign culture of their new homes. That makes the situations when these women after their death got their ethnic weapons (!) put into their burials, in the course of funeral rituals, all the more important. That means that just the fact of placing the weapon to the grave was important for their afterlife destiny, it was significant for these women personally and it may be considered a witness of involuntary acknowledgement of foreign ritual culture, foreign for these women's new families. Ethnic Greeks and Hellenistic rites prevailed in the necropolis of Tanais town in the $2^{\text {nd }}-1^{\text {st }}$ cc. BCE. At that time, Tanais' relations with nomads were quite stable (actually, the town did not use fortification; there is no evidence of raids etc.). Throughout time, regular mixed marriages (however occasional) has been the strongest indicator of allied partnership between neighboring peoples. Eight female graves with weapons, discovered in different parts of the Western 


\section{Global Journal of Archaeology \& Anthropology}

Necropolis, can serve as an example of partnership relations. Among more numerous deceased women and children (14 из 17), two graves of women-warriors with Sarmatian weapons -arrows in a quiver (grave 34) or a spear (grave 50) - were discovered in 2002. These women-warriors were rather "middle aged" for their epoch, about 30 years old. The grave with arrows - is a poor one, whereas the woman in the grave with a spear has a gold ring and earrings.

This richer grave, together with two neighboring ones, belonging to a man and a child, differs in its shape from domineering common pits (Figure 11). Unfortunately, drawings of other parts of the early necropolis are not available. However, female graves are known to usually have arrows here. This differentiates these graves from synchronous burials of
Saramaian women in the neighboring Steppe; the latter mostly have swords. However, another balance between different types of weapons for women who got to foreign environment is quite natural (such balance is typical for Bosporan Greek men of that time). Many of above-mentioned women were included into local elite; they had gold costume accessories (earrings, rings, dress appliqués). Attempts of colleagues, who have researched such graves, to claim these personages from Tanais to be patriarchal Greek women - "shut-ins" [22] are quite bewildering. Another series of Sarmatian wives' graves, containing weapons, belonging to the late $2^{\text {nd }}$ - early $3^{\text {rd }} \mathrm{cc}$. CE has been discovered in fortified settlements of Maeotes, who were dependent on nomads (Kobyakovo, grave 38, excavation trench II, 2002; SukhoChaltyrskoe, grave 12; Temernitskoe, 2002 y.) [27] (Figure 12).
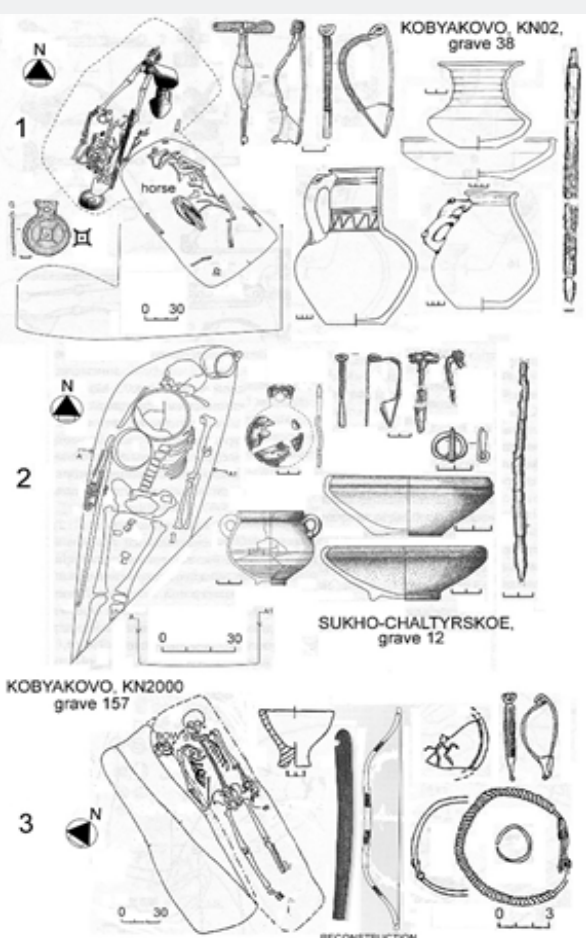

Figure 12: Late Sartmaian wives with weapons in Meotean hillforts of Don Mouth [27].

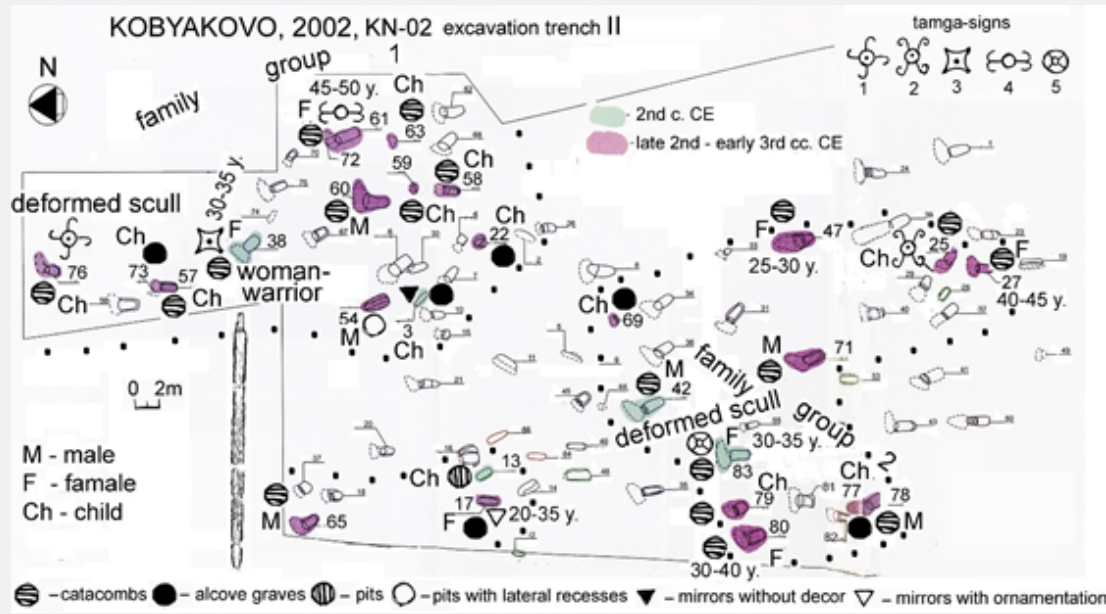

Figure 13: Sarmatian woman-warrior grave' context in Maeotian Kobyakovo hillfort, 2002 y. [27]. 


\section{Global Journal of Archaeology \& Anthropology}

It is well known that in the neighboring Kuban Basin, where not a long time before Maeotes had migrated from, female graves with weapons have not been discovered at all. These women (being 35-45 years old, a rather venerable age at that time) had only one and highly specific item of weaponry - a long horseman's sword (!). The only warrior woman of earlier Middle Sarmatian time (late $1^{\text {st }} \mathrm{c}$. CE) was considerably younger (20-25 лет) and had another weaponry item, more unusual for a woman, a bow pasted over with bone pates and without $t$ arrows (Kobyakovo, grave 157, excavation trench KN-2000) [28]. Among Paired Graves with Husband or Father other grave goods there were miniature mirrors with Sarmatian tamga (which are traditionally accepted as marriage attribute of Sarmatian women who got married to foreign lands) [29]. The planigraphic context of a warrior woman's grave with a sword from Kobyakovo is indicative (Figure 13). The grave is placed in the center of "a family cluster" of 12 burials and it is the earliest one among them. There are children's graves to the west from it and there is a line of aged grown-ups' graves to the east of it (the line is oriented from north to south); the eastern side of the burial cluster is also fringed with children's graves.

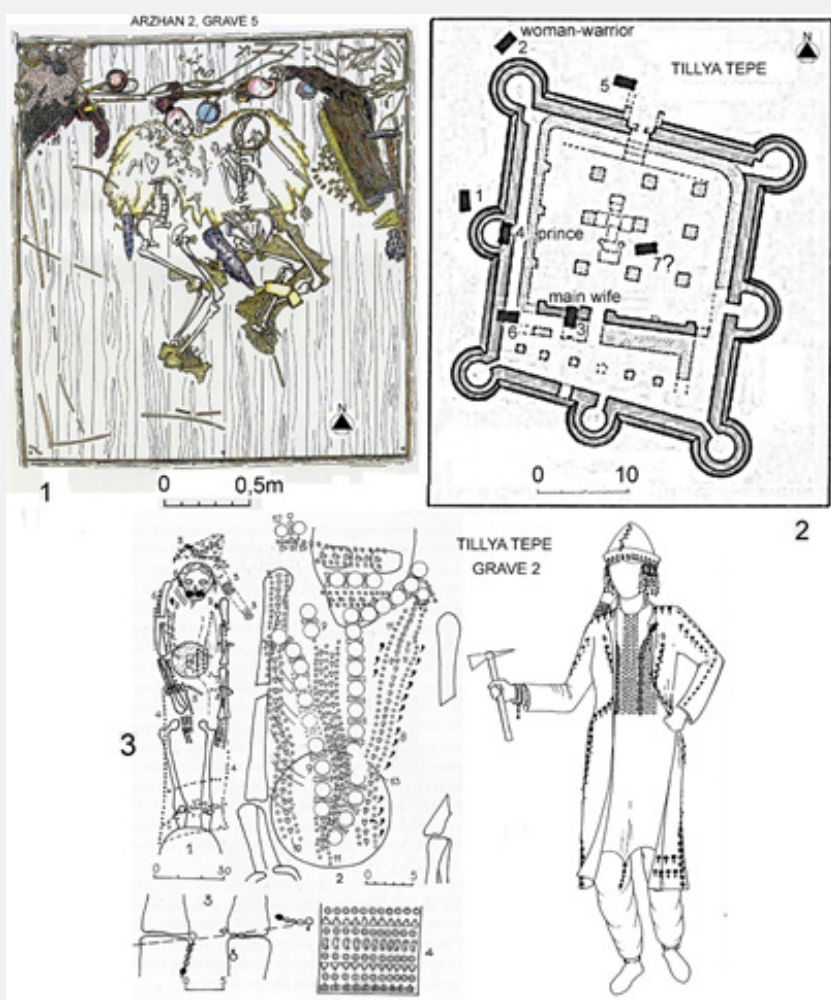

Figure 14: Burial of a woman-warrior with her husband (?): 1 - Azhan 2; 2 - Tillya Tepe necropolis of prince and his harem; 3 - the grave of woman-warrior in Tillya Tepe.

In the Scythian Epoch in different regions of the Steppe Zone we know a small series of paired burials: a warrior woman together with or close to her probable husband (her peer or, more often, older than her). Such burials could look different: in one grave (including in one and the same coffin) or in two neighboring graves. In cases of burials in the same grave anthropologists have never identified battle wounds; probably, death was due to epidemics and famine. Such graves are rare, such as in Arzhan-2 [30] (Figures 1 \& 14). It is significant that in large Scythian necropolises there are no such graves (Skel'ki), or there is only one (Mamai-Gora, barrow 45; Elizavetovskoe, barrow 51, grave 2). In small necropolises of the Scythian time, such case is always the only one both for Scythians (Kut, barrow 7, grave 9; Tri Brata, barrow 2), Scythizated Forest-Steppe Zone tribes (Kholodnyi Yar, barrow 20) and Sirmates (Sladkovka, barrow 4). The cases when a man was much older than women and could be either a husband or a father (Mamai-Gora, barrow
36) are very rare. Such cases when only the woman was armed (Volga-Ural Rivers Region: Novonikol'skoe, barrow 5, grave 4; Pokrovka 8, barrow 6, grave 3) [comp. 3] present particular interest.

In the later Sarmatian Epoch we observe another tradition: the burial of a warrior woman and her probable husband inпогребенthe barrow where there were only two graves belonging to adults (Novyi, barrows 63, 75, 84, 92, 95). On such occasions one of the spouses was buried near the other some years later. The family necropolis of a ruler with graves of his 6 wives surrounding it, in Tillya Tepe (female grave No 7 was looted by soldiers) represents a special case (Figure 15). Here the ruler's wives were laid around in two arcs (three graves from south-east and three from north-west, with the most influential wife of the group in the center of each arc). The graves of the most important wives with the richest costume and attributes of 
high status (including "the main wife" in grave 3) were, probably, located up there, inside the ancient fortress; less important wives (taken form territories or families less significant for their husband) were, probably, buried down there, at the fortress' foot. A young woman from grave 2 has the status attribute of the same significance as in synchronous Sarmatians graves - a battleaxe [31].

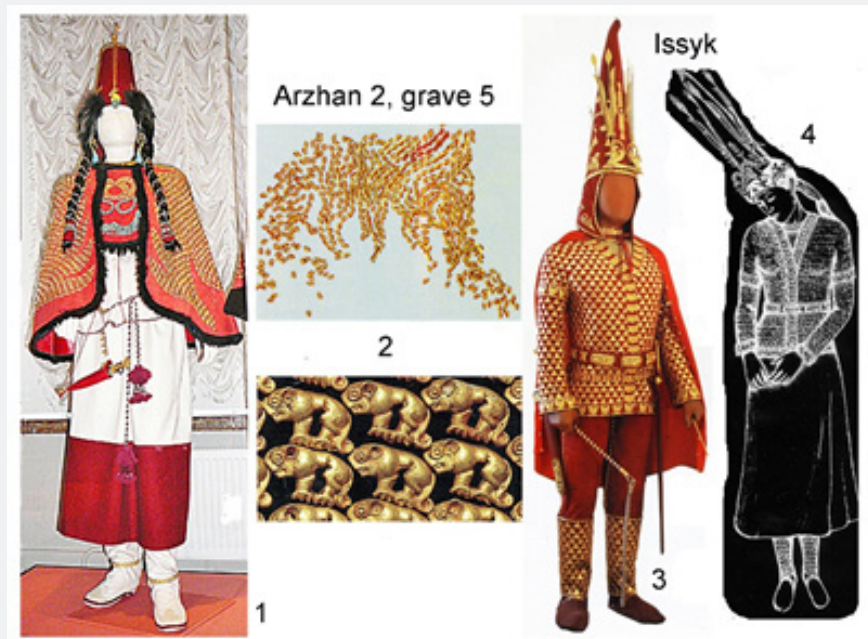

Figure 15: Costume of Scythian-Saka time women-warriors:1 - author photo; 2 - pelerine, V.K. Chugunov photo; 3 - K. Altynbekov reconstruction, 1996; 4 - T. Terekulov and N. Terekulova reconstruction, 2000.

Costume

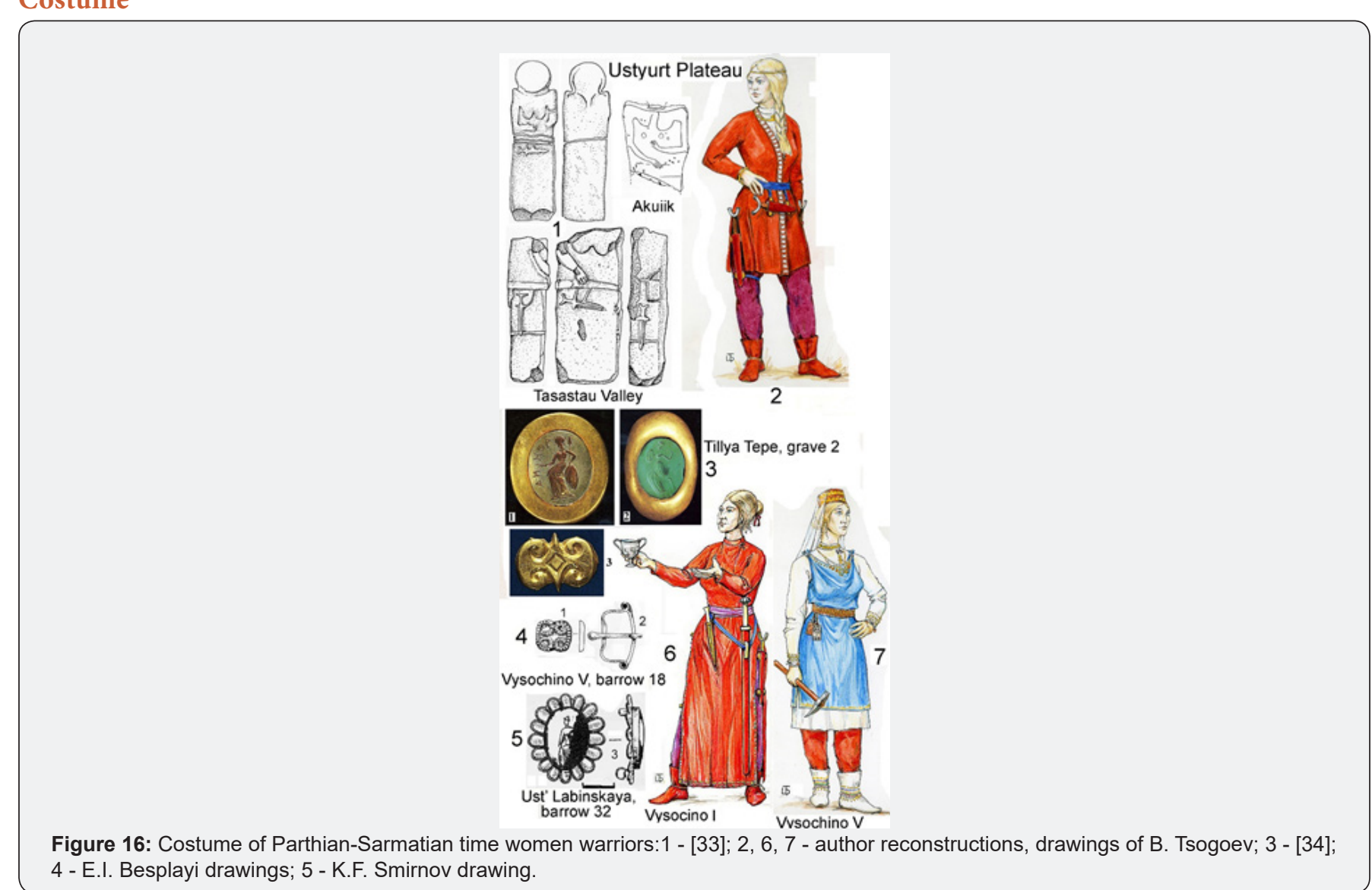

The costume of women in wartime environment in the Eurasian Steppe was of two basic types: copying the male' one in its main elements and female' with additional details comfortable for horse-riding, more seldom - with specific headdresses. The both variants existed up to the beginning of the Middle Ages [19,32] (Figures 16 \& 17). I note also a wide warrior belt for the statues of the $3^{\text {rd }}-1^{\text {st }}$ cc. BCE from Usturt Plateau sanctuaries (Akuiik [33] (Figure 1, 16) and for female ruler of Yazamates - Polyaen. Strat. 8. 55). It is interesting that Greek mythological symbolic, connected with warrior women, 
spread among nomadic barbarians after campaigns of Alexander the Great and appearance of large Hellenistic states. We see similar visual images in décor elements of groups as remote as Sarmatians of the Don Mouth (Vysochino) or the Kuban River (Ust'-Labinskaya) and the Yuezhi of Bactria (Tillya Tepe) [34] in the mid. $1^{\text {st }}$ - early $3^{\text {rd }}$ cc. CE. It is décor of noble warrior women' dresses with golden applications with schematic images of double axe (labrys) - the main attribute of Amazons in Greek art [35] (Figure 3,4 \& 16) and the images of Athena - the Goddess of War on the seal-rings and brooches [36] (Figure 3(3),5 \& 16). In most cases there is no reason to think that armed women were put into graves exactly in battlefield clothes.

\section{Conclusion}

Most likely in those tribal groups of early nomads that were often drafted into serious conflicts all healthy women on reaching marriageable age (that is after 12 years old) were military trained, as Herodotus and Pomponius Mela described, during collective hunting and small armed confrontations. The necessity of women's total mobilization arose very seldom, and not everybody took place in the battle... Bodies of most women killed at the war stayed at the battlefield and have been met at clan cemeteries in small numbers. It is interesting to know that women buried with arms are over 25-30 years old, which means they were buried after long years of married life and giving birth to many children. Whereas, at much younger age, (exactly at the active period of fulfilling their social function of defenders) usually, there are no items of weaponry among their grave gifts. In every community, women's weapon sets differ from men's; it is well illustrated by materials from large necropolises.

Probably, placing weapon items into graves was connected with two factors: special personal military merits and family (or husband's) status at the moment of the woman's death. More prestigious weapon than usual arrows could depend on the age group (Mamai-Gora) or traditions of a certain clan connected with one of grave types (Novyi). Relatives did not seek (and, notwithstanding their wish, could not do it) put into the grave the complete set of the woman's weapons she used to have in her younger days. Relatives could place the weapon of their own into the woman's grave. It could be the weapon that was analogous to the one she herself used once to have. In most cases, some arrows, and for Sarmatian noble women a single battleax, were enough to denote their military (and continued to be an important factor of their self-identification that was also recognized in foreign communities. There are conclusively known necropolises where a small number of armed women took the honorable place in the cemetery composition and had the biggest number of high rank attributes and unusual ritual artifacts as their grave gifts.

However, for most common female participants of war campaigns it was only some more additional and cruel exploitation in a patriarchal society. Generally, warrior women were actively used and partly had prestige in those regions with dense nomadic population and best pastures for which there was frenzied competition in Scythia (the Lower Dnepr and NW
Azov Coast) and in Sarmatia (the Lower Don). In the 4th c CE the number of armed women increased in connection with active disintegration of Scythia; whereas in Saramatia it happened in the early 1 st and middle 2 nd cc. CE due to two migration waves from the depths of Central Asia. According to some anthropologists, the ancestors of the tribes of Middle Sarmatian Culture were the late Sakas of NW of Xinjiang [37] and the ancestors of the tribes of Late Sarmatian Culture were the peoples of Late Tagar Cultur of Upper Yenisei Basin in Khakasia [38] (but, according to the kind advice of Egor P. Kitov, both cultures have their motherland in Aral Sea Region).

\section{References}

1. Kaloev BA (1959) Amazons Motif in Ossetian "Nart" Epic Poems (Motiv amazonok v osetinskom nartovskom epose), Kratkie soobshcheniia Intituta ethnografii, USSR AS, Russian, XXII: 45-51.

2. Bogachenko TV (2017) Historical Base of the Legends of Women-Warriors of South Russian Steppes (Istoricheskie osnovy skazanii o zhenshchinakh voitel'nitsakh yuzhnorusskikh stepei). Rostov-on-Don, Taganrog: Yuzhnii federal'nyi universitet, Russian. pp. 217-218.

3. Fialko EE (2017) The Series of Scythian Female Warriors' Burials from the Cemetery near Glinoe Village (Moldova) (Seriia pogrebenii skifskikh voitel'nits us. Glinoe (Moldova). Arkheologiia i starodavniaia istoriia Ukrainy, Russian. 2(23): 209.

4. Fialko EE (2015) Amazons in Time and Space (Amazonki vo vremeni i prostranstve). Arkheologiia i davyaya istoriia Ukrainy, Russian, 5: 62$63,66-67,72-73$.

5. Bogachenko TV (2011) Women-warriors of the South Russian Steppes: The Historical Base of Legends (Zhenshchiny-voitel'nitsy yuzhnorusskikh stepei: Istoricheskie osnovy skazanii). Saarbrücken: LAP Lambert Academic Publ, Russian, pp. 153-156, 185-187.

6. Andrukh SI, Toshchev GN (1999-2001-2004-2009) Mamai-Gora Necropolis (Mogil'nik Mamai-Gora). Vols. I-IV. Zaporozhie: Zaporozhie National Univ Press, Russian.

7. Il'yukov LS, Vlaskin MV (1992) Sarmatians of the Interfluve of Sal and Manych (Sarmaty mezhdurechia Sala i Manycha). Rostov-on-Don: Izdatel'stvo Rostovskogo gosudarstvennogo universiteta, Russian, pp. 30-142.

8. Batieva EF (2011) Population of the Lower Don Basin in the $9^{\text {th }}$ c. BCE $-4^{\text {th }}$ c. CE (paleoanthropological study) (Naselenie Nizhnego Dona v IX v. do n.e. - IV v. n.e. (paleoantropologicheskoe issledovanie). Rostov-onDon: Yuznyi nauchnyi tsentr RAN, Russian, pp. 99-103.

9. Popandopulo ZKh (2011) The Scythian Ground Necropolis Skel'ki (Skifskii gruntovyi mogol'nik Skel'ki). Zaporozhie: Zaporozhskii oblastnoi kraevedcheskii muzei, Russian.

10. Vdovchenkov EV (2013) Male and Female in the Burial Rituals and in Society of Sarmatians of Don Basin (on the Materials of Novyi Barrow Necropolis) ("Muzhskoe" i "zhenskoe" v pograbal'nom obryade i obshchestve sarmatov Podonia (po materialam kurgannogo mogilnika Novyi). Uchitel', Russian, 4: 287-294.

11. Yatsenko SA, Vdovchenkov EV (2015) On Some Aspects of Military Organization of the Ancient Nomads of European Steppe (O nekotorykh storonakh voennoi organizatsii drevnikh kochevnikov evropeiskoi Stepi). Znanie. Ponimanie. Umenie, Russian, 1: 176-177.

12. Yatsenko SA (2016) On the Study of Planigraphy of Big Sarmatian Necropolises (K izucheniiu planigrafii krupnykh sarmatskikh nekropolei). Konstantin Federovich Smirnov i sovremennye problemy sarmatskoi arkheologii. Yablonsky LT, Kraeva LA (Eds.), Orenburg: Izdatel'stvo Orenburgskogo gosudarsvennohgo pedagogicheskogo univeriteta, Russian, pp. 317. 


\section{Global Journal of Archaeology \& Anthropology}

13. Yatsenko SA (2017) Planigraphy of Scythian Necropolis Mamai-Gora (Planigrafiia skifskogo mogil'nika Mamai-Gora). Starozhitnosti stepovogo Prichornomor'ia i Krymu, Russian, XX: 262-263.

14. Popandopulo ZKh (2011) Scythian Ground Cemetery Skel'ki (Skifskii gruntovyi mogil'nik Skel'ki). Zaporozhie: Zaporozhskii oblastnoi kraevedcheskii muzei, Russian.

15. Polin SV (2014) Scythian Barrow Necropolis Zolotaia Balka of the $5^{\text {th }}-4^{\text {th }}$ cc. BCE in Kherson Region (Skifskii Zolotobalkovskii kurgannyi mogil'nik V-IV vv. do n.e. na Khersonshchine. Kiev: Oleg Filyuk, Russia.

16. Pererva EV, Lukyashko SI (2011) On the Semantics of Scalping Ritual of Early Sarmatians (O semantike obriada skal'pirovaniia u rannikh armatov). Pogrebal'nyi obriad rannikh kochevnikov Evrazii. Matishev GG, Yablonsky LT, Lukyashko SI (Eds.), Rostov-on-Don: Yuznyi nauchnyi tsentr RAN, Russian, pp. 383.

17. Yatsenko SA (2016) Sarmatian Necropolis of the second half of the $1^{\text {st }}$ early $2^{\text {nd }} \mathrm{cc}$. CE near Ust'-Kamenka Village: the Planigraphic Specificity (Sarmatskii mogil'nik 2-i poloviny I - nachala II vv. n.e. u s. Ust'-Kamenka: osobennosti planigrafii). Starozhitnosti stepovogo Prichornomor'ia i Krymu. Russian, XIX: 201-203.

18. Bespalyi EI, Luk'iashko SI (2008) The Ancient Population of the Don and Kagal'nik Interfluve. The Barrow Necropolis near Vysochino Village (Drevenee naselenie mezhdurechia Dona i Kagal'nika. Kurganny mogil'nik us. Vysochino). Rostov-on-Don: Iuzhnyi nauchnyi tsentr RAN, Russian.

19. Yatsenko SA (2015) Costume of the Women-Warriors of the Early Nomads (Kostium zhenshchin-voitel'nits u rannikh kochevnikov). Moda i dizain: istoricheskii opyt - novye tekhnologii. Materialy XVIII-i mezhdunarodnoi konferentsii. ed. N.M. Kalashnikova. St Petersburg: Gos. universitet tekhnoogii i dizaina, Russian, p. 47-56.

20. Balabanova MA, Pererva EV, Klepikov VM, Krivosheev MV, Demkin VA, et al. (2014) Barrow Necropolis Peregruznoe I: The Results of Interdisciplinary Study (Kurgannyi mogil'nik Peregruznoe I: rezul'taty mezhdistsiplinarnykh issledovanii). Volgograd: Volgograd Branch, Russian Academy of National Economy and Public Service,Russian.

21. Bezuglov SI, Glebov VP, Parusimov IN (2009) The Late Sarmatian Graves in the Don Mouth (the Barrow Necropolis Valovyi I) (Pozdnesarmatskie pogrebeniia v ust'e Dona (kurgannyi mogil'nik Valovyi I)). Rostov-on-Don: Media-Polis,Russian.

22. Glebov VP, Tolochko IV (2016) Female Graves with Weapons in the Lower Don Basin in the Late Hellenistic Epoch: Tanais and Sarmatians (Zhenskie pogrebeniia s oruzhiem na Nizhnem Donu v epokhu pozdnego ellinizma: Tanais i sarmaty). Antichnaia tsivilizatsiia i varvarskii mir Ponto-Kaspiiskogo regiona. Luk'iashko SI (Eds.), Rostov-on-Don Yuznyi nauchnyi tsentr, RAS, Russian, p. 55-58.

23. Khazanov AM (1971) Essays on the Military Art of Sarmatians (Ocherki voennogo dela u sarmatov). Nauka, Moscow, Russian, p. 51.

24. Shevchenko OB (2018) Ritual Function of the Weapons Usage in the Female Graves of Sarmatians - Spears, Swords, Axes (Rutual'na funktsiia predmetiv ozbroennia u zhinochikh pokhovanniakh sarmativ - spisy, mechi, sokiry). Arkheologiia, ethnologiia ta okhorona kul'turnoi spadshchiny Pivdenno-Shidnoi Evropy. ed. O.D. Smintina. Odessa: Odesskii Natsional'nyi Universitet, Ukrainian, pp. 224-231.

25. Shevchenko OB (2019) The Female Graves with Weapons of Sarmatians (Zhinochi pokhovannia zi zbroeiu u sarmativ). PhD Diss. Thesis Summary. Kyiv: Institut Arkheologii, NAN Ukrainy, Ukrainian.
26. Yatsenko SA (2008) Ancient Instruments in the Cultures of Sarmatians and Late Scythians (Drevnie orudiia v kul'ture sarmatov i pozdnikh skifov). Nizhnevolzhskii arkheologicheskii vestnik. Russian, 9: 117-126.

27. Larenok VA (2016) Maeotean Antiquities. Cataloque of the Burial Complexes of Kobyakovo Hill-Fort from the Excavations of 2000-2001, 2002, 2004 yy. (Meotskie drevnosti. Katalog pogrebal'nykh kompleksov Kobyakova gorodishcha iz raskopok 2000-2001, 2002, 2004 godov). Part II. Rostov-on-Don: Donskoi izdatel'skii dom, Russian, 76: 39.

28. Larenok VA (2013) Maeotean Antiquities. Cataloque of the Burial Complexes of Kobyakovo Hill-Fort from the Excavations of 1999-2000 yy. (Meotskie drevnosti. Katalog pogrebal'nykh kompleksov Kobyakova gorodishcha iz raskopok 1999-2000 gg.). Part I. Rostov-on-Don: Donskoi izdatel'skii dom, Russian, p. 82-83.

29. Yatsenko SA (2018) Planigraphy of Tamga-Signs in the Necropolises of Sedentary Population in Sarmatia (Planigrafiia znakov-tamg v nekropoliakh osedlogo naseleniia Sarmatii). Stratum plus. Russian, 6: 217-242.

30. Čugunov KV, Parzinger H, Nagler A (2003) Der scythische Fürstengrabhügel von Aržan 2 in Tuva. Vorbericht der russisch-deutschen Ausgrabungen 2000-2002. Eurasia Antiqua. 9: 18.

31. Yatsenko SA (2001) The Costume of the Yuech-Chich / Kushans and Its Analogies to the East and to the West. Silk Road Art and Archaeology. 7: 73-120.

32. Yatsenko SA (2006) Costume of the Ancient Eurasia (the Iranian-Speaking Peoples) (Kostium drevnei Evrazii (ironiazychnye narody)). Moscow: Vostochnaya literatura, Russian, pp. 340-341.

33. Samashev Z, Ongar A, Oralbai E, Kiyasbek G (2011) The Temple-Sanctuary Kyzyluiik (Khram-sviatilishche Kyzyluiik). Astana: Arkheologiia, Russian.

34. Sarianidi VI (1985) Bactrian Gold from the Excavations on the Tillya-Tepe Necropolis in the Northern Afghanistan. Leningrad: Avrora, 42: 108-109.

35. Schaub IYu (2007) Myth, Cult and Ritual in the North Pontic Region (the $7^{\text {th }} 4^{\text {th }}$ cc. BCE) (Mif, kul't i ritual v Severnom Prichernomorie (VIIIV vv. do n.e.)). St Petersburg: Phylologicheskii Fakul'tet St Petersburgskogo Universiteta, Russian, pp. 109.

36. Yatsenko SA (2018) Women-Warriors of the Early Nomads" the Social Status, Equipment and Costume (Zhenshchiny-voitel'nitsyu rannikh kachevnikov: sotsial'nyi status, ekipirovka i kostium). Muzhskoi i zhenskii mir v otrazhenii arkheologii. Rafikova YAv (Eds.), Ufa: Institut istorii, yazyka i literatury Ufimskogo issledovatel'skogo tsentra RAN, Russian, pp. 212.

37. Chikisheva TA (2011) Physical Anthropology of the Early Nomads of South Siberia and Central Asia (Fizicheskaia antropologiia rannikh kochevnikov Iuzhnoi Sibiri i Tsentral'noi Azii). "Terra Scythica". The Proceedings of International Symposium. Molodin VI, Hansen S (Eds.), Novosibirsk: Institut arkheologii i ethnografii, Sibirskoe otdelenie RAN, Russian.

38. Balabanova MA (2012) On the Central Asiatic Communications in Anthropology of the Late Sarmatian Time Population of Eastern Europe ( 0 tsentral'noaziatskikh sviaziakh $\mathrm{v}$ antropologii naseleniia pozdnesarmatskogo vremeni Vostochnoi Evropy). Vestnik arkheologii, anthropologii i ethnografii, Russian, 3: 87-88 
(C) (i) This work is licensed under Creative

BY DOI: 10.19080/GJAA.2019.08.555742

\section{Your next submission with Juniper Publishers} will reach you the below assets

- Quality Editorial service

- Swift Peer Review

- Reprints availability

- E-prints Service

- Manuscript Podcast for convenient understanding

- Global attainment for your research

- Manuscript accessibility in different formats

( Pdf, E-pub, Full Text, Audio)

- Unceasing customer service

Track the below URL for one-step submission https://juniperpublishers.com/online-submission.php 